\title{
Carcass characteristics and meat quality of Nellore females reared in an intensive system using progesterone ear implant
}

\section{Características da carcaça e qualidade da carne de fêmeas Nelore criadas em sistema intensivo utilizando implante auricular de progesterona}

\author{
Rafael Alves da Costa Ferro ${ }^{1 *}$; Aldi Fernandes de Souza Franca ${ }^{2}$; \\ Emmanuel Arnhold ${ }^{2}$; Claudia Peixoto Bueno ${ }^{1}$; Diogo Alves da Costa Ferro ${ }^{1}$; \\ Aracele Pinheiro Pales Santos ${ }^{1}$; Klayto José Gonçalves Santos ${ }^{1}$; \\ Eliane Sayuri Miyagi ${ }^{2}$
}

\begin{abstract}
This study was carried out to evaluate the influence of a synthetic progesterone ear implant on weight gain and meat quality of Nellore heifers. Twenty-eight Nellore heifers with an average initial weight of $240.9 \mathrm{~kg}$ were used in this experiment. All heifers received the same dietary management, in an intensive rearing system, with mineral salt and water ad libitum. Heifers were distributed, in a completely randomized design, into two treatments (with and without progesterone ear implant) with seven replications, in 14 stalls. Analysis of variance was performed, and, for non-parametric variables, the Kruskal-Wallis test was applied. Parameters referring to the meat quantitative and qualitative characteristics, represented by the weight and yield of the carcass, conformation, marbling, color, meat texture, carcass morphometric measurements, longissimus dorsi muscle area, and fat thickness, were not affected by the progesterone hormone. The use of the progesterone ear implant did not change the carcass physical characteristics or the meat quality characteristics.
\end{abstract}

Key words: Feedlot. Hormone. Performance. Zebu.

\section{Resumo}

Este trabalho foi realizado para avaliar a influência do implante auricular de progesterona sintética sobre ganho de peso e na qualidade de carne de novilhas Nelore. Foram utilizadas 28 novilhas Nelore com peso inicial médio de $240,9 \mathrm{~kg}$. Todas as novilhas receberam o mesmo manejo alimentar, em sistema intensivo de criação, com sal mineral e água ad libitum. Foram distribuídas em delineamento inteiramente casualizado, com dois tratamentos (com e sem implante auricular de progesterona) e sete repetições, em 14 baias, com a realização de análise de variância e para as variáveis não paramétricas foi realizado o teste de Kruskal-Wallis. Os parâmetros referentes às características quantitativas e qualitativas da carcaça e da carne, representados pelo peso e rendimento da carcaça, conformação, marmoreio, coloração, textura da carne, medidas morfométricas da carcaça, área do músculo Longissimus dorsi e espessura de gordura não foram afetados pelo hormônio progesterona. A utilização do implante auricular de progesterona,

\footnotetext{
${ }^{1}$ Profs. Drs., Curso de Zootecnia, Universidade Estadual de Goiás, UEG, São Luís de Montes Belos, GO, Brasil. E-mail: rafael. ferro@ueg.br; vetcpb@gmail.com; diogo.ferro@ueg.br; aracele.pales@ueg.br; klayto.santos@ueg.br.

2 Profs. Drs., Escola de Veterinária e Zootecnia, Universidade Federal de Goiás, UFG, Goiânia, GO, Brasil. E-mail: aldi_franca@ ufg.br; emmanuelarnhold@yahoo.com.br; eliane.miyagi@gmail.com

* Author for correspondence
} 
não alterou as características físicas da carcaça e a qualidade da carne.

Palavras-chave: Confinamento. Desempenho. Hormônio. Zebuíno.

\section{Introduction}

In Brazil, beef cattle are mostly finished on pasture, and the feedlot system is used in smaller proportions. However, the feedlot can be used as a strategy in the pre-weaning, post-weaning, and finishing stages to accelerate the development of animals and provide an increase in the number of cattle finished per year, thereby contributing to the growth of the national livestock sector (ALMEIDA et al., 2010).

The Nellore breed is ranked first in number of heads in the Brazilian herd because of its rusticity. This breed participates in the national livestock in pure or crossbred herds with excellent meat production performance, which can exceed $1.2 \mathrm{~kg}$ / day (MARQUES, 2003). Marques et al. (2000) reported an average daily gain of $1.6 \mathrm{~kg}$ for Nellore $\times$ European crossbred animals.

The vast majority of meat consumed in Brazil does not have defined quality patterns, originating from different categories such as cows, oxen, heifers, and steers; however, consumers are seeking products of better quality that do not harm the environment (COUTINHO FILHO et al., 2006). As a result, the cattle farming activity has undergone some changes in recent years that have affected its efficiency and profitability. Therefore, innovative research is being conducted and techniques are being investigated so as to improve quality meat production at a lower cost and in less time (VERA et al., 2013). For the best sale of this meat to be possible, the carcass classification is a parameter of great importance (MOREIRA et al., 2012).

According to Rotta et al. (2010), to determine the quality of bovine carcasses, characteristics such as loin-eye area, texture, color, fat thickness, marbling, conformation, yield, and carcass weight should be taken into consideration. Leg length, round thickness, and carcass length are also important measurements, in this regard (ROTTA et al., 2009). In the different production systems, either extensive or intensive, the use of females for meat production requires differentiated management techniques, since pregnancy is an undesirable occurrence (SILVA et al., 2005) for slaughterhouses and for good animal welfare.

Hormones such as estrogen and progesterone play an important role in body growth and development that benefit the synthesis and deposition of fat, as they act as regulators of many chemical reactions, with important functions in physiological processes and body development (GOMIDE et al., 2013). As a strategy to evaluate the effect of this hormone on the beef quality, synthetic hormones and other techniques can be employed by using an intravaginal device or a progesterone ear implant.

According to Marques et al. (2007) producers seek methods to reduce the incidence of estrus, aiming to finish females in a shorter time, since the expression of estrus in these animals causes disorders, stress, and the risk of injury, which may affect their intake and weight gain. An option to eliminate the effect of estrus is the use of a device to simulate pregnancy and the finishing of females in early pregnancy.

This study was carried out to evaluate the influence of synthetic progesterone ear implant on weight gain and meat quality of Nellore females.

\section{Material and Methods}

The experiment was conducted on Escola Farm, at the State University of Goiás, in São Luís de Montes Belos-GO, Brazil (16 31'20' S and $\left.50^{\circ} 22^{\prime} 48^{\prime \prime} \mathrm{W}\right)$, where the average temperature and humidity during the experimental period (May 
to June 2014) were $25{ }^{\circ} \mathrm{C}$ and $52 \%$, respectively, measured using a thermo-hygrometer. Experimental procedures complied with and were approved by the Ethics Committee in Animal Use (CEUA) of the Federal University of Goiás.

Twenty-eight Nellore heifers (Bos indicus indicus), all in estrus, at an average age of 20 months, were kept in the feedlot for 60 days. The animals were distributed at random into 14 stalls at two heifers per stall, receiving the same treatment. The same environment was provided to all animals, and each stall measured $24 \mathrm{~m}^{2}$.

Before entering the feedlot, 14 females received a progesterone ear implant (with three milligrams of norgestomet) subcutaneously. The implant was changed every 15 days so that the plasma progesterone concentration would not be lost, and animals had them on until 15 days before the slaughter. The group with ear implant had an average initial weight of $243.9 \mathrm{~kg}$, while that without the implant weighed $237.85 \mathrm{~kg}$, on average.

Corn silage was supplied during the entire confinement period, together with a concentrate containing ground corn, soybean meal, soybean hulls, livestock urea, and a mineral-vitamin mix. Feed was supplied four times daily, distributed at 06.00, 10.00, 13.00 and $17.00 \mathrm{~h}$, and feed intake was monitored by weighing the feed supplied and refusals.

Every 15 days, all experimental animals were taken to the management corral and weighed on a digital scale placed immediately after the restraint chute, which allowed us to check the influence of the progesterone hormone on the weight gain, besides determining the final weight $(\mathrm{FW})$, total weight gain (TWG), and average daily weight gain (ADG). Animals were weighed after being fasted for $12 \mathrm{~h}$, starting at $18.00 \mathrm{~h}$ and ending at $06.00 \mathrm{~h}$.

Heifers were slaughtered in a slaughterhouse in Aurilândia - Goiás, following the current legal procedures (BRASIL, 2007). The heifers were stunned by brain concussion with a captive bolt pistol, which aims at rendering them unconscious during slaughter so that they can be killed efficiently and painlessly, remaining immobilized to be suspended for the subsequent bleeding by sectioning the large vessels. After the slaughter, carcasses were weighed and identified by tags with the number of the animal and stored in a cold room at $4{ }^{\circ} \mathrm{C}$ until the following morning for carcass evaluations.

Hot carcass yield was calculated as the ratio between hot carcass weight and final live weight, with the result multiplied by $100 \%$ (ROTTA et al., 2010).

Color, marbling, and texture were evaluated after the carcass was chilled for a period of $24 \mathrm{~h}$, on the longissimus dorsi muscle cut between the $12^{\text {th }}$ and $13^{\text {th }}$ ribs. The marbling degree was determined by the amount of intramuscular fat, as follows: 1 to $3=$ traces; 4 to $6=$ light; 7 to $9=$ little; 10 to $12=$ medium; 13 to $15=$ moderate; 16 to $18=$ abundant. Texture was classified according to the particle size displayed when the muscle surface was cut $(1=$ highly coarse; $2=$ coarse; $3=$ slightly coarse; $4=$ fine; 5 = highly fine).

A colorimeter was used to determine the meat color, after exposing the cut to air for $30 \mathrm{~min}$, using the CIELab system, in which the lightness ( $\left.\mathrm{L}^{*}\right)$ is related to the water-holding capacity - the higher the water content, the higher the $L^{*}$ value -, ranging from 0 to 100 (pure black to pure white). The letter $a^{*}$ represents the intensity of red, varying from red $\left(+\mathrm{a}^{*}\right)$ to green $\left(-\mathrm{a}^{*}\right)$, and the higher its value, the redder the meat. The yellow intensity is represented by the letter $b^{*}$, ranging from yellow $\left(+b^{*}\right)$ to blue $\left(-b^{*}\right)$, and higher $b^{*}$ values determine a more yellowish meat (RAMOS; GOMIDE, 2012).

Conformation was assessed subjectively, using profiles that demonstrate the development of different muscle masses. The grades (Brazilian system) of data for this classification are: very convex, convex, straight, concave, or very concave (MOREIRA et al., 2012). 
The carcass length was evaluated using a tape measure, by extending it from the cranial edge of the ischium-pubis to the medial cranial edge of the first rib. We also evaluated thigh length (distance between the front edge of the pubic bone and a middle point of the tibiotarsal-joint bones), thigh circumference (by surrounding the middle region of the thigh with a tape measure), leg length (distance between the tuberosity of the olecranon and the radiocarpal joint), and leg circumference (by surrounding the middle region of the leg with a tape measure).

The carcass fatness degree was determined based on the distribution and amount of fat at the $6^{\text {th }}$, $9^{\text {th }}$, and $12^{\text {th }}$ ribs, classifying it as: lean (1) - absent fat; sparse fat (2) - 1 to $3 \mathrm{~mm}$ thickness; moderate fat (3) - 3 to $6 \mathrm{~mm}$ thickness; uniform fat (4) - 6 to $10 \mathrm{~mm}$ thickness; and excess fat (5) - over $10 \mathrm{~mm}$ thickness.

To evaluate the loin-eye area $\left(\mathrm{cm}^{2}\right)$ a one-inch $(2.54 \mathrm{~cm})$ thick section was made on the longissimus dorsi muscle, and the muscle was outlined onto tracing paper. This area was later measured with a checkered plastic sheet that contains a point in the center of each square, the basic measurement of each square being $1 \mathrm{~cm}^{2}$. The sheet was placed on the tracing paper and the number of points within the muscle drawing was counted, generating the loin-eye area in $\mathrm{cm}^{2}$. The same muscle was used to determine fat thickness, which was measured using a caliper.

The experiment was conducted as a completely randomized design, with two treatments (with and without progesterone ear implant) and seven replications, using 14 stalls at two animals per stall. Computer software R version 2.15.2 was used for the statistical analyses, allowing the comparison of performance between both treatments, with analysis of variance. For non-parametric variables, the Kruskal-Wallis was applied.

\section{Results and Discussion}

The initial and final weights of the treatment groups were similar $(\mathrm{P}>0.05)$, with respective values of 243.9 and $333.6 \mathrm{~kg}$ for the heifers with the implant and 237.8 and $331.5 \mathrm{~kg}$ for those without it (Table 1). This non-significant difference may be explained by the breed pattern and the diet and environment to which the experimental animals were subjected. These data corroborate the results found by Silva et al. (2005), who reported final weight gains of 327.6 and $334.0 \mathrm{~kg}$ for heifers without and with an intrauterine device, respectively.

Table 1. Mean values for initial and final weight (kg), total weight gain (TWG), average daily weight gain (ADG), and carcass dressing percentage (CD) of Nellore heifers with and without ear implant.

\begin{tabular}{|c|c|c|c|c|c|}
\hline \multirow{2}{*}{ Treatment } & \multicolumn{2}{|c|}{ Implant } & \multirow{2}{*}{ Mean \pm SD } & \multirow{2}{*}{ CV (\%) } & \multirow{2}{*}{$\mathrm{P}$} \\
\hline & Without & With & & & \\
\hline Initial weight, $\mathrm{kg}$ & 237.85 & 243.92 & $240.88 \pm 14.16$ & 5.87 & 0.32 \\
\hline Final weight, kg & 331.46 & 333.63 & $332.55 \pm 20.66$ & 6.21 & 0.84 \\
\hline TWG, kg & 93.64 & 89.71 & $91.67 \pm 15.05$ & 16.42 & 0.63 \\
\hline $\mathrm{ADG}, \mathrm{kg}$ & 1.44 & 1.38 & $1.41 \pm 0.23$ & 16.31 & 0.63 \\
\hline $\mathrm{CD}, \%$ & 50.30 & 51.34 & $50.82 \pm 1.23$ & 2.42 & 0.16 \\
\hline
\end{tabular}

Not significant ( $>>0.05)$; CV (\%): coefficient of variation; SD: standard deviation.

Comparing both groups, with and without the implant, no difference $(\mathrm{p}>0.05)$ was found for the
TWG and ADG values, which were 89.7 and 93.6 $\mathrm{kg}$ and 1.38 and $1.44 \mathrm{~kg}$, respectively. Vera et al. 
(2013) obtained, in their studies with Nellore cows, weight gains of $49.9 \mathrm{~kg}$ for the group with the implant versus $34.1 \mathrm{~kg}$ for the cows without it, but without statistical differences. Abba et al. (2010) did not detect differences in weight gain between heifers with and without intrauterine balls, used to suppress estrus. Wada et al. (2008) worked with Nellore heifers at 18 months of age in the feedlot and observed an average daily weight gain of 1.17 $\mathrm{kg}$, considered satisfactory for the animal category utilized.

Dressing percentage, the characteristic considered economically desirable at fattening, was $51.3 \%$ and $50.3 \%$ for the groups with and without the implant, respectively. Despite this $1.0 \%$ variation, there was no difference $(p>0.05)$ between the treatments, indicating that treatments did not change carcass dressing. Rubiano et al. (2009) stated that cattle subjected to the same feedlot period and dietary regime, with similar carcass weight and the same physiological maturity, show similar carcass dressing percentages. Silva et al. (2005) found CD values of $47.1 \%$ and $46.9 \%$ for the groups without and with intrauterine device, respectively. Vera et al. (2013) also did not observe differences in their study. Silva et al. (2006) found CD values of 53.6\% for castrated heifers with the use of rubber ring in the ovarian pedicle, and $52.8 \%$ for intact females.

Despite the observed numerical difference between the groups with and without the progesterone ear implant, the characteristics were not influenced by reproductive condition (Table 2).

Table 2. Mean values for marbling, texture, backfat thickness, and fat degree of Nellore heifers with and without ear implant.

\begin{tabular}{|c|c|c|c|c|c|}
\hline \multirow{2}{*}{ Variable } & \multicolumn{2}{|c|}{ Implant } & \multirow{2}{*}{ Mean \pm SD } & \multirow{2}{*}{ CV (\%) } & \multirow{2}{*}{$\mathrm{P}$} \\
\hline & Without & With & & & \\
\hline Marbling & 4.57 & 6.71 & $5.64 \pm 1.93$ & 34.21 & 0.06 \\
\hline Texture & 2.71 & 2.85 & $2.78 \pm 0.72$ & 25.89 & $0.71 *$ \\
\hline $\mathrm{BFT}, \mathrm{mm}$ & 4.95 & 5.28 & $5.12 \pm 1.19$ & 23.24 & 0.60 \\
\hline Fat degree & 3.21 & 3.50 & $3.35 \pm 0.73$ & 21.79 & $0.33 *$ \\
\hline
\end{tabular}

*Kruskal-Wallis non-parametric test; Not significant ( $p>0.05)$; CV (\%): coefficient of variation; SD: standard deviation.

Heifers with and without the ear implant showed respective marbling values of 4.6 and 6.7, indicating a slight amount of intramuscular fat. No significant difference was observed, though, possibly due to the heterogeneity of results, confirmed by the coefficient of variation. Marques et al. (2006) also did not find significant differences for marbling in their studies with heifers originating from a cross between Nellore and Angus, with an average value of 3.7, which can be considered less 'light' marbling and more 'traces'.

With regard to meat texture, females without the implant had an average value of 2.7 , whereas those with the implant averaged 2.8 , indicating that the particle size of the muscle surface shows a coarseto-slightly coarse texture when it is cut. Pardi et al. (2001) stated that the coarse texture, not desirable for meat, may result from the bundles of muscle fibers and increased thickness of connective tissue fasciae.

Mean values for fat thickness (FT) of 5.0 and 5.3 $\mathrm{mm}$ were found in heifers with and without the ear implant, respectively, showing the precociousness of the Nellore breed for fat deposition. These results agree with those reported by Restle et al. (2002), who found superior fat thickness for Nellore compared with Charolais cows. Both FT values found in the experiment meet the Brazilian market requirements 
determined by slaughterhouses. According to Rotta et al. (2010), in Brazil, for good sale of beef, the backfat thickness must be between 3 and $6 \mathrm{~mm}$. Fat thickness values lower than $3 \mathrm{~mm}$ may cause problems due to cold, which leads to shortening of the sarcomeres (rigor mortis) during storage in the cold room (KAZAMA et al., 2008). These authors found an average BFT of $3.3 \mathrm{~mm}$ in their studies with Nellore-Angus crossbred heifers. In both treatments, mean values for fattening degree were higher than score 3 , considered medium, indicating presence of a fat layer in the region of rump, lumbar, and lateral face of the round. Silva et al. (2007) also did not find differences in their studies, in which they found the scores of 2.6 for castrated heifers and 2.8 for intact heifers. Moreira et al. (2012) obtained a fattening degree of 2.3, which is lower than that obtained here, in heifers aged up to two years, and noted a positive correlation between fattening degree and maturity of the animals.
With the subjective assessment of the carcass profiles, the presence of straight, concave, and convex conformations was found at the frequencies of $64.3 \%, 28.5 \%$, and $7.2 \%$ respectively, related to the carcass muscularity. These data corroborate the results published by Moreira et al. (2012), who found a larger number of straight carcasses, which may be associated with diet, breed, and maturity of animals. The sub-convex profile is the most desired, according to Costa et al. (2007), as it indicates greater yield.

As regards loin-eye area, there was no difference $(p>0.05)$ between treatments (Table 3$)$. The average LEA found in the experiment was $46.4 \mathrm{~cm}^{2}$, which is lower than the $50.8 \mathrm{~cm}^{2}$ found by Kazama et al. (2008) with crossbred (Nellore vs. Angus) heifers. Loin muscle is an indicator of muscle development, because as this value increases, the edible portion of the carcass also increases.

Table 3. Mean values for loin-eye area (LEA), thigh length, thigh circumference, leg length, leg circumference, and carcass length of Nellore heifers with and without ear implant.

\begin{tabular}{|c|c|c|c|c|c|}
\hline \multirow{2}{*}{ Variable } & \multicolumn{2}{|c|}{ Implant } & \multirow{2}{*}{ Mean \pm SD } & \multirow{2}{*}{ CV $(\%)$} & \multirow{2}{*}{$\mathrm{P}$} \\
\hline & Without & With & & & \\
\hline LEA, $\mathrm{cm}^{2}$ & 46.14 & 46.60 & $46.37 \pm 3.74$ & 8.06 & 0.82 \\
\hline Thigh length, $\mathrm{cm}$ & 72.36 & 71.64 & $72.00 \pm 1.70$ & 2.36 & 0.44 \\
\hline Thigh circ., $\mathrm{cm}$ & 54.14 & 52.58 & $53.36 \pm 1.86$ & 3.48 & 0.16 \\
\hline Leg length, $\mathrm{cm}$ & 46.50 & 46.92 & $46.71 \pm 1.63$ & 3.49 & 0.63 \\
\hline Leg circ., $\mathrm{cm}$ & 33.35 & 34.35 & $33.85 \pm 1.56$ & 4.60 & 0.25 \\
\hline Carcass length, $\mathrm{cm}$ & 131.93 & 133.64 & $132.78 \pm 2.79$ & 2.10 & 0.27 \\
\hline
\end{tabular}

Not significant $(\mathrm{p}>0.05)$; CV $(\%)$ : coefficient of variation; SD: standard deviation.

Silva et al. (2007) worked with Nellore heifers and found significant differences for the variable longissimus area, which averaged $54.4 \mathrm{~cm}^{2}$ and $47.0 \mathrm{~cm}^{2}$ for intact and castrated animals, respectively. Marques et al. (2006), however, in an experiment with Nellore vs. Red Angus crossbred heifers, obtained an average longissimus muscle of $57.3 \mathrm{~cm}^{2}$, without differences between treatments (heifers in estrous cycle; with lead balls in the uterine horns; and without ovary). This characteristic is influenced by the age sex, size, breed, and weight of the animal.

The carcass characteristics did not show differences $(p>0.05)$ between treatments. Mean values for thigh length, thigh circumference, leg length, leg circumference, and carcass length were 
$72.0,53.4,46.7,33.8$, and $132.8 \mathrm{~cm}$, respectively. Restle et al. (2002) observed the respective values of $126.7,74.6,42.5$, and $33.3 \mathrm{~cm}$, for carcass length, thigh length, leg length, and leg circumference in Nellore cows. Kuss et al. (2005) found lower values than those obtained in our study, with cows originating from rotational crossbreeding between Charolais and Nellore.

Analyzing the different aspects of color in the hindquarter and longissimus dorsi muscle (Table 4), we observed that the treatments had no statistical difference $(\mathrm{p}>0.05)$. The meat color is a parameter of great importance when it comes to sale, considered one of the most appealing traits. Fernandes et al. (2008) observed that meat from young animals has a cherry color, which is appreciated by consumers due to the lower myoglobin $(\mathrm{Mb})$ levels. Ramos an Gomide (2012) stated that myoglobin is the main agent responsible for the meat pigment, at around $90 \%$, hemoglobin being the second $(\mathrm{hB})$ in importance. These authors also reported that meats with a red color - cherry or bright red - are usually from young animals.

Table 4. Mean values for the color of hindquarter and longissimus dorsi muscle of Nellore heifers with and without ear implant.

\begin{tabular}{|c|c|c|c|c|c|c|c|}
\hline \multirow{2}{*}{ Variable } & & & \multicolumn{2}{|c|}{ Implant } & \multirow{2}{*}{ Mean \pm SD } & \multirow{2}{*}{ CV (\%) } & \multirow{2}{*}{$\mathrm{p}$} \\
\hline & & & Without & With & & & \\
\hline \multirow{6}{*}{ Color } & \multirow{3}{*}{ Hindquarter } & $\mathrm{L}^{*}$ & 32.66 & 33.31 & $32.98 \pm 3.38$ & 10.25 & 0.72 \\
\hline & & $a^{*}$ & 20.84 & 18.24 & $19.54 \pm 3.81$ & 19.50 & 0.22 \\
\hline & & $\mathrm{b}^{*}$ & 9.61 & 8.76 & $9.18 \pm 2.34$ & 25.49 & 0.51 \\
\hline & \multirow{3}{*}{$\begin{array}{l}\text { Longissimus } \\
\quad \text { dorsi }\end{array}$} & $\mathrm{L}^{*}$ & 38.04 & 36.78 & $37.41 \pm 2.75$ & 7.35 & 0.40 \\
\hline & & $\mathrm{a}^{*}$ & 18.09 & 17.88 & $17.98 \pm 2.74$ & 15.23 & 0.89 \\
\hline & & $b^{*}$ & 9.78 & 9.85 & $9.81 \pm 1.66$ & 16.91 & 0.93 \\
\hline
\end{tabular}

$\mathrm{L}^{*}$ : lightness; $\mathrm{a}^{*}$ : red intensity; $\mathrm{b}^{*}$ : yellow intensity; Not significant ( $\left.\mathrm{p}>0.05\right)$; CV (\%): coefficient of variation; SD: standard deviation.

All coefficients of variation found in this experiment were considered relatively low between 2.10 and $34.57 \%$-, indicating little instability of the studied samples. Sampaio (2007) asserted that the coefficient of variation for animal responses ranges from $20 \%$ to $30 \%$, but given that coefficients can go from 0 to $100 \%$, there was no variation between the observed values, or there was great instability.

\section{Conclusion}

In the conditions of the present study, the use of progesterone ear implant did not change the carcass physical characteristics or meat quality characteristics of Nellore heifers. Further, weight gain was also not influenced by the use of this device.

\section{References}

ABBA, M. G.; FELICIANO, M. A. R.; VICENTE, W. R. R. Ganho de peso de novilhas mestiças submetidas ou não à esterilização pela introdução intrauterina de esferas inoxidáveis e ao uso ou não de modificador orgânico. Arquivo Brasileiro de Medicina Veterinária e Zootecnia, Belo Horizonte, v. 62, n. 2, p. 289-292, 2010.

ALMEIDA, R.; MEDEIROS, S. R.; CALEGARE, L.; ALBERTINI, T. Z.; LANNA, D. P. D. Fazendas de terminação. In: PIRES, A. V. Bovinocultura de corte. Piracicaba: FEALQ, 2010. p. 183-199. 
BRASIL. Ministério da Agricultura, Pecuária e Abastecimento. Inspeção de carnes bovina: padronização de técnicas, instalações e equipamentos. Secretaria de Defesa Agropecuária, Poder Executivo, Brasília, nov. 2007. 168 p. Disponível em: <www.agricultura.gov.br/ arq_editor/image/Animal/manual_carnes.pdf $>$. Acesso em: 03 ago. 2016.

COSTA, C.; MEIRELlES, P. R. L.; SAVASTANO, S.; ARRIGONI, M. B.; ROÇA, R. O.; MOURÃO, G. B. Desempenho produtivo e características de carcaça de bovinos inteiros e castrados criados no sistema superprecoce. Veterinária e Zootecnia, Botucatu, v. 14, n. 2, p. 252-259, 2007.

COUTINHO FILHO, J. L. V.; PERES, R. M.; JUSTO, C. L. Produção de carne de bovinos contemporâneos, machos e fêmeas, terminados em confinamento. Revista Brasileira de Zootecnia, Viçosa, MG, v. 35, n. 5, p. 20432049, 2006.

FERNANDES, A. R. M.; SAMPAIO, A. A. M.; HENRIQUE, W.; OLIVEIRA, E. A.; TULLIO, R. R.; PERECIN, D. Características da carcaça e da carne de bovinos sob diferentes dietas, em confinamento. Arquivo Brasileiro de Medicina Veterinária e Zootecnia, Belo Horizonte, v. 60, n. 1, p. 139-147, 2008.

GOMIDE, L. A. de M.; RAMOS, E. M.; FONTES, P. R. Ciência e qualidade da carne: fundamentos. Viçosa, MG: UFV, 2013. 197 p.

KAZAMA，R.; ZEOULA，L. M.; PRADO, I. N.; SILVA, D. C.; DUCATTI, T.; MATSUSHITA, M. Características quantitativas e qualitativas da carcaça de novilhas alimentadas com diferentes fontes energéticas em dietas à base de cascas de algodão e de soja. Revista Brasileira de Zootecnia, Viçosa, MG, v. 37, n. 2, p. 350357, 2008.

KUSS, F.; RESTLE, J.; BRONDANI, I. L.; PASCOAL, L. L.; MENEZES, L. F. G.; PAZDIORA, R. D.; FREITAS, L. S. Características da carcaça de vacas de descarte de diferentes grupos genéticos terminados em confinamento com distintos pesos. Revista Brasileira de Zootecnia, Viçosa, MG, v. 34, n. 3, p. 915-925, 2005.

MARQUES, D. C. Criação de bovinos. 7. ed. Belo Horizonte: CVP Consultoria Veterinária e Publicações, 2003. 586 p.

MARQUES, J. A.; PRADO, I. N.; ALBUQUERQUE, K. P.; KUTSUNUGI, E.; SCAMPARIN, V. X.; CALDAS NETO, S. F. Indução do anestro em novilhas confinadas. Desempenho, conversão alimentar e digestibilidade. Archivos de Zootecnia, Córdoba, v. 56, n. 215, p. 343346, 2007.
MARQUES, J. A.; PRADO, I. N.; MOLETTA, J. L.; PRADO, I. M.; PRADO, J. M.; MACEDO, L. M. A.; SOUZA, N. E.; MATSUSHITA, M. Características físico-químicas da carcaça e da carne e novilhas submetidas ao anestro cirúrgico ou mecânico terminadas em confinamento. Revista Brasileira de Zootecnia, Viçosa, MG, v. 35, n. 4, p. 1514-1522, 2006.

MARQUES, J. A.; PRADO, I. N.; ZEOULA, L. M.; ALCALDE, C. R.; NASCIMENTO, W. G. Avaliação da mandioca e seus resíduos industriais em substituição ao milho no desempenho de novilhas confinadas. Revista Brasileira de Zootecnia, Viçosa, MG, v. 29, n. 5, p. 15281536, 2000.

MOREIRA, P. S. A.; BERBER, R. C. A.; LOURENÇO, F. J.; BELUFI, P. R.; KONRAD, M. Efeito do sexo e da maturidade sobre o peso de carcaça quente, acabamento e conformação de bovinos abatidos em Sinop-MT. Comunicata Scientiae, Bom Jesus, v. 3, n. 4, p. 292-298, 2012.

PARDI, M. C.; SANTOS, I. F.; SOUZA, E. R.; PARDI, H. S. Ciência, higiene e tecnologia da carne. 2. ed. Goiânia: UFG, 2001. 623 p.

RAMOS, E. M.; GOMIDE, L. A. M. Avaliação da qualidade de carnes: fundamentos e metodologias. Viçosa, MG: UFV, 2012. 599 p.

RESTLE, J.; PASCOAL, L. L.; FATURI, C.; ALVES FILHO, D. C.; BRONDANI, I. L.; PACHECO, P. S.; PEIXOTO, L. A. O. Efeito do grupo genético e da heterose nas características quantitativas da carcaça de vacas de descarte terminadas em confinamento. Revista Brasileira de Zootecnia, Viçosa, MG, v. 31, n. 1, p. 350362, 2002.

ROTTA, P. P.; PRADO, I. N.; PRADO, R. M. Desempenho, qualidade da carcaça e da carne de bovinos. In: PRADO, I. N. Produção de bovinos de corte e qualidade da carne. Maringá: EDUEM, 2010. p. 191-242.

ROTTA, P. P.; PRADO, R. M.; PRADO, I. N.; VALERO, M. V.; VISENTAINER, J. V.; SILVA, R. R. The effects of genetic groups, nutrition, finishing systems and gender of Brazilian cattle on carcass characteristics and beef composition and appearance: a review. AsianAustralasian Journal of Animal Sciences, Seoul, v. 22, n. 12, p. 1718-1734, 2009.

RUBIANO, G. A. G.; ARRIGONI, M. B.; MARTINS, C. L.; RODRIGUES, E.; GONÇALVES, H. C.; ANGERAMI, C. N. Desempenho, características de carcaça e qualidade de carne de bovinos superprecoces das raças Canchim, Nelore e seus mestiços. Revista Brasileira de Zootecnia, Viçosa, MG, v. 38, n. 12, p. 2498-2498, 2009. 
SAMPAIO, I. B. M. Estatística aplicada à experimentação animal. 3. ed. Belo Horizonte: FEPMVZ, 2007. 264 p.

SILVA, H. L.; MEIRINHOS, M. L. G.; OLIVEIRA FILHO, B. D.; GORDO, J. M. L. Efeitos da utilização do dispositivo intra-uterino (DIU) sobre o ganho de peso e o rendimento de carcaça de novilhas Nelore destinadas ao abate. Ciência Animal Brasileira, Goiânia, v. 6, n. 2, p. 95-103, 2005.

SILVA, L. A. F.; PALES, A. P.; CRISTIANO, S. P.; FIORAVANTI, M. C. S.; PÁDUA, J. T.; SILVA, O. C.; MIYAGI, E. S.; SANTOS, K. J. G.; BARBOSA, V. T. Características de carcaça e carne em novilhas castradas ou não-castradas da raça Nelore. Ciência Animal Brasileira, Goiânia, v. 8, n. 4, p. 777-785, 2007.
SILVA, L. A. F.; PALES, A. P.; FIORAVANTI, M. C. S.; PÁDUA, J. T.; SILVA, O. C.; SANTOS, K. J. G. Anel de látex aplicado no pedículo ovariano de bezerras Nelore. Acta Scientiarum Animal Sciences, Maringá, v. 28, n. 1, p. 97-103, 2006.

VERA, J. H. S.; SILVA, K. M. B.; YAMADA, P. H.; SILVA, L. F. B.; PACHECO, T. M.; CAMPIONI, F.; LUQUETTI, B. C.; SOUTELlO, R. V. G. Ganho de peso e acabamento de carcaça em vacas da raça Nelore implantadas com dispositivo intra-uterino bovino (DIUB). Ciências Agrárias e da Saúde, Andradina, v. 9, p. 16-20, 2013.

WADA, F. Y.; PRADO, I. N.; SILVA, R. R.; MOLETTA, J. L.; VISENTAINER, J. V.; ZEOULA, L. M. Grãos de linhaça e de canola sobre o desempenho, digestibilidade aparente e características de carcaça de novilhas Nelore terminadas em confinamento. Ciência Animal Brasileira, Goiânia, v. 9, n. 4, p. 883-895, 2008. 
